A Szegedi Tudományegyetem, Általános Orvostudományi Kar, Ortopédiai Klinika ${ }^{1}$ és a Debreceni

Egyetem, Orvos és Egészségtudományi Centrum, Általános Orvostudományi Kar, Ortopédiai Klinika²

közleménye

\title{
Dabigatran és enoxaparin használata során nyert tapasztalataink csípőprotézis beültetést követően
}

\author{
DR. GOMBÁR CSABA ${ }^{1}$, DR. GÁLITY HRISTIFOR ${ }^{1}$, DR. GYŐRFI GYULA², \\ DR. SOHÁR GELLÉRT ${ }^{1}$, DR. SISÁK KRISZTIÁN ${ }^{1}$, DR. TÓTH KÁLMÁN ${ }^{1}$
}

\section{ÖSSZEFOGLALÁS}

Egyre gyakrabban alkalmazzák elektív csípőprotézis beültetés után a szájon keresztül adható tromboprofilaktikus szereket. Klinikai vizsgálatok szerint az új direkt trombin inhibitor dabigatran etexilát tromboprofilaktikus hatékonysága és major vérzéses szövődmény rátája megegyezik a kis molekulasúlyú heparinok csoportjába tartozó enoxaparinéval. A szerző́k célja a klinikai vizsgálatok során a minor vérzéses szövődmények és a sebgyógyulást befolyásoló tényezők részletes vizsgálata dabigatran és enoxaparin használatakor. Elektív cementes csípőprotézis beültetésen átesett betegeket a perioperatív időszakban alkalmazott antikoagulánsok szerint két csoportba sorolták a szerzők: az enoxaparint és a dabigatrant használók csoportjába. Megfigyelték a combtérfogat változását, a számított perioperatív vérveszteséget, a haematoma nagyságát a bőrfelszínen, a sebvérzést, a sebváladékozás időtartamát és annak intenzitását a mútét utáni harmadik és hetedik napon. A vizsgálatba összesen 140, mindkét csoportba 70-70 beteget vontak be. A dréncső eltávolítása után a sebváladékozás időtartama szignifikánsan nagyobb, $2,3( \pm 2,7)$ nap a dabigatrant használóknál, míg az enoxaparint használóknál ez $1,2( \pm 1,9)$ nap volt $(p<0,05)$. A dabigatrant használók csoportjában a serosus sebváladékozás mértéke szignifikánsan nagyobb a mútét utáni harmadik és hetedik napon is. Mindkét antikoaguláns szernek megfelelő a trombózist megelőző hatása teljes cementes csípőprotézis beültetést követően. Dabigatran használata során kialakuló elhúzódó időtartamú és nagyobb mennyiségű serosus váladékozás megemelheti a sebgyógyulási szövődmények, így a reoperációk gyakoriságát.

\section{Kulcsszavak: $\quad$ Antikoagulánsok; Arthroplastica; Csípőprotézis;} Dabigatran; Enoxaparin; Posztoperativ kezelés; Thromboembolia; Trombin-gátlók; Tromboprofilaxis;

Cs. Gombár, H. Gálity, Gy. Győrfi, G. Sohár, K. Sisák, K. Tóth: Our experiences with the use of dabigatran and enoxaparine as thromboprophylactic agents following primary total hip replacement

Orally applicable antithrombotic agents are frequently used following elective total hip replacement as the thromboprohylactic medication of choice. Clinical trials have demonstrated that the new direct thrombin inhibitor, dabigatran etexilate has an equivalent major bleeding profile if compared with the low molecular weight heparin enoxaparine. The aim of the current study was the detailed comparison of the minor bleeding complications and wound healing problems following the use of either dabigatran or enoxaparine. We have divided our patients undergoing elective cemented total hip replacement into two groups, according to the thromboprophylactic agent received during the perioperative period: patients receiving dabigatran and patients receiving enoxaparine. Observed parameters included: change in thigh volume, calculated perioperative blood loss, size of haematoma as observed on the skin, wound oozing, length of time of wound discharge and its intensity on the 3rd and 7th postoperative day. 140 patients were included in the study, 70 in each group. The time of wound discharge after drain removal was significantly longer in patients using dabigatran $2,3( \pm 2,7)$ days, than patients receiving enoxaparine 1,2 $( \pm 1,9)$ days $(p<0,05)$. Patients receiving dabigatran had significantly more wound discharge on the $3 \mathrm{rd}$ and 7th postoperative day. Both anticoagulants were found to have the requested thromboprohylactic effect after primary elective total hip replacement. The use of dabigatran was associated with a longer period of 
wound discharge with more frequent serous oozing. This might increase the incidence of wound healing complications, and might potentially lead to higher reoperation rate.

Key words: $\quad$ Anticoagulants - Therapeutic use;

Arthroplasty, replacement, hip - Adverse effects;

Enoxaparin - Parmacology;

Postoperative care - Methods; Thrombin - Antagonists \& inhibitors;

Thromboembolism - Prevention \& control;

\section{BEVEZETÉS}

Teljes csípő endoprotézis (csípő TEP) beültetés után gyakran alakul ki vénás tromboembolia (VTE) (10), ami megfelelő gyógyszeres és mechanikus tromboprofilaktikus módszerekkel jelentősen csökkenthető. Jelenleg, csípőprotézis beültetés után, a következő gyógyszeres trombózismegelőző hatóanyagok vannak használatban: kis molekulasúlyú heparinok (low-molecular-weight heparins, LMWH), nem frakcionált heparin (unfractioned heparin, UFH), pentaszacharid, szájon keresztül alkalmazható aktivált X-es faktor és direkt trombingátló szerek, továbbá az Amerikai Egyesült Államokban acetilszalicilsav és $\mathrm{K}$-vitamin antagonista szerek is (KVA) (13, 15). Két évtizedes klinikai gyakorlat és számos vizsgálat után az LMWH-k a farmakológiai tromboprofilaxis bázis terápiájává váltak (23).

$\mathrm{Az}$ elmúlt években a direkt trombin inhibitor dabigatran etexilát, az aktivált X-es faktort gátló apixaban és rivaroxaban is az elektiv csípő- és térdprotézis beültetést követő gyógyszeres tromboprofilaxis elfogadott módszereivé váltak $(19,23)$. A közölt adatok szerint az új szerek trombózis megelőző hatása egyenlő vagy akár jobb is, mint a vizsgálatok során öszszehasonlító szerként használt enoxapariné. A vizsgálati eredmények azonban e szerek használatakor nagyobb vérzéses szövődmény gyakoriságot is mutatnak $(5-8,23)$. Egyre több klinikai vizsgálat, illetve a korábbi adatokat áttekintő tanulmány szerint, a posztoperatív vérzés és sebfertőződés kockázata nagyobb rivaroxaban és dabigatran használatakor (12, 16).

A dabigatran etexilát kifejlesztése során a csípőprotézis beültetés körüli trombózis megelőző hatását elemző klinikai vizsgálatok főleg a nagy, illetve a klinikai szempontból jelentős vérzéses szövődményekre, mint biztonsági végpontokra figgyeltek. Résziletesen nem is. mertették azokat a sebészi szempontból különösen fontos szempontokat, mint az új hatóanyag sebgyógyulást, sebváladék és a mútéti sebfertőződés gyakoriságát befolyásoló hatását $(6,8)$.

Célunk volt összehasonlítani a dabigatran és enoxaparin biztonsági profilját a klinikai gyakorlatban, különös figyelmet fordítva a kisebb vérzéses szövődményekre és sebgyógyulást befolyásoló hatásokra a korai posztoperatív időszakban.

\section{ANYAG ÉS MÓDSZER}

2011 márciusától 2012 májusáig prospektív módon gyűjtöttük és vontunk be minden beteget, akik primer cementes csípő TEP beültetésen esett át coxarthrosis vagy combfej avascularis necrosisa miatt. E betegeket két csoportra osztottuk az alkalmazott perioperatív antikoagulánsok szerint. Egyik csoportban a LMWH-k csoportjába tartozó enoxaparint (Clexane $^{\circledR}$, Sanofi-Aventis), a másik csoportban a szájon keresztül alkalmazható direkt trombin inhibitor dabigatran etexilátot $\left(\operatorname{Pradaxa}^{\circledR}\right.$, Boehringer Ingelheim International) kapták. A betegek bevonása az egyes csoportokba a hetenként változó gyógyszerellátmány szerint történt: a páros héten mútött betegek enoxaparint, míg a páratlan heteken dabigatrant kaptak az operáltak.

A nem szteroid gyulladáscsökkentő szerek (non-steroidal anti-inflammatory drug, NSAID) és az acetilszalicil-sav adagolását egy héttel a mútét időpontja előtt leállítottuk. A mútét előtt ellenőriztük a vese- és májfunkciót, az aktivált parciális tromboplasztin időt (activated partial thromboplastin time, aPTT), protrombin időt (prothrombin time, PT) a nemzetközi normalizált rátát (international normalized ratio, INR). Vizsgálatunkba nem vontuk be azokat a betegeket, akiknek revíziós 
mútéte, vese és/vagy májfunkció zavara, véralvadási zavara (21) volt és/vagy az állandóan antikoaguláns terápiára szorulókat (pl. acenokumarol, warfarin, clopidogrel).

Vizsgálatunkban a választott véralvadásgátlókat az Egészségügyi Minisztérium jelenleg érvényes, tromboemboliák megelőzésére és kezelésére vonatkozó szakmai irányelvei szerint, illetve az Országos Gyógyszerészeti Intézet álláspontja és a hatóanyagok alkalmazhatóságának előírásai szerint alkalmaztuk (22). Az egyik csoportban subcutan $40 \mathrm{mg}$ enoxaparint kezdtünk a mútét előtt 12 órával, majd a mútét napjától kezdve minden este 8 órakor adtuk 28-35 napig. A másik csoportban a 75 éves kor alatti betegek $220 \mathrm{mg}$ dabigatran etexilátot, míg a 75 év felettiek $150 \mathrm{mg}$ dabigatran etexilátot kaptak. E gyógyszer adagolását mútét után 4 órával fél dózissal (110 mg illetve $75 \mathrm{mg}$ ) kezdtük, majd a mútét utáni első naptól kezdve napi egyszer reggel 8 órakor a teljes dózist kapták 28-35 napig $(11,19)$.

A mútéti beavatkozásokat általános, vagy regionális, vagy a kettőt kombináló anesztézia alatt kiviteleztük az aneszteziológus indikációjától függően. A mütéteket összesen hét, SZTE ÁOK Ortopédiai Klinikán dolgozó, ortopéd sebész végezte el, direkt lateralis vagy Bauer-féle feltárásból. Minden beteg cementes csípő TEP-et kapott. A mútétek során és a korai posztoperatív időszakban nem használtunk cell-savert vagy egyéb autológ transzfúziót lehetővé tevő vérgyűjtő rendszert. A mútéteket antibiotikumos védelemben végeztük, amihez cefuroximot vagy penicillin allergia esetén clindamycint használtunk. A mútétet követő 24 órában kettő darab szívódrént helyeztünk a mútéti területbe, a drénváladékot beosztással rendelkező Redon ${ }^{\circledR}$-palackokban gyújtöttük. A dréncső eltávolítása után mútéti sebet és a szívócsövek kilépési helyét meghatározott méretű, Mepore ${ }^{\circledR}$-típusú kötszerrel fedtük.

Szükség szerinti fájdalomcsillapítóként paracetamolt, tramadolt és metamizole-t adtunk. A gyógytornát az első mútét utáni napon kezdtük, addukciót és kirotációt tiltva, teljes testsúlyterheléssel a mütött végtagon.

A kis vérzéses szövődmények, illetve a klinikailag szignifikáns és a nagy vérzéses szövődmények korábbi publikációk és irányelvek alapján kerültek megfigyelésre $(6,9)$. A trombózisos szövődmények a klinikai gyanú esetén kerültek kivizsgálásra és feljegyzésre.

\section{Trombózis és tromboembolia}

Alsó végtagi fájdalom, duzzanat, jelentős ödéma, livid elszíneződés, pozitív Mayer- és Homans-tünet fennállásakor színkódolt Doppler ultrahangos vizsgálatot végeztünk a mélyvénás trombózis (MVT) kizárására (20). Pulmonális embólia (PE) ġyanúja (fiul!adás, nem szűnő köhögési inger, vérköpés, mellkasi fájdalom stb.) esetén az intézeti protokoll szerint, a mellkas computer tomográfiás angiográfiás (CTA) vizsgálatát végeztük el. A mútét után 3 hónappal telefonon felkerestük a betegeket, hogy kezelték-e őket más intézményben MVT vagy PE miatt.

\section{Nagy és klinikailag jelentős vérzéses szövőd- mények definíciója}

Nagy vérzéses szövődménynek tekintjük a haláltokozó vérzést, a $20 \mathrm{~g} / \mathrm{L}$-nél nagyobb hemoglobinesést okozó vérzést, az azonnali 2 vagy annál több egység vörösvértest koncentrátum transzfúzióját igénylő vérzést, a retroperitonealis, intracranialis, intraocularis vagy intraspinalis vérzéseket, illetve a reoperációhoz vezető, nem szűnő vérzéseket. Klinikailag jelentős vérzésnek tekintjük a $25 \mathrm{~cm}^{2}$ vagy annál nagyobb testfelületen spontán jelentkező bőr haematomákat, a 100 $\mathrm{cm}^{2}$ vagy annál nagyobb mútéti seb körül kialakuló bőr felszíni haematómát, a spontán orr-és ínyvérzéseket, amik 5 percnél hosszabb ideig fennállnak, a 24 óránál hosszabb ideig tartó spontán és/vagy beavatkozás során kialakuló makroszkópos haematuriát, illetve minden egyéb vérzéses eseményt, ami klinikailag jelentősnek bizonyul (6-8).

Összehasonlításra került a két csoport között a számított perioperatív vérveszteség ( $V$, $\mathrm{ml})$ is. E számításhoz ismernünk kell a beteg magasságát $(H, c m)$, testsúlyát $(G, k g)$, mútét előtti hematokrit értékét (Hct $)_{0}$ és a mútét utáni első napon mért hematokrit értéket $\left(\mathrm{Hct}_{1}\right)$. Azok a betegek, akik a mútét utáni első vérvételig transzfúzióban részesültek, nem kerültek bele ebbe az összehasonlításba. A Nadler-képletet használva kaptuk meg a számított perioperatív vérveszteséget (18):

$$
\mathrm{V}=\mathrm{EBV} x \ln \left(\mathrm{Hct}_{0} / \mathrm{Hct}_{1}\right)
$$


$A$ becsült vér térfogatot (estimated blood volume, EBV) a következő képlettel számítottuk ki:

$$
E B V=A \times H^{0,725} \times G^{0,425}-B
$$

ahol $A=0,0236$ a férfiaknál; $A=0,0248$ a nőknél; $B=1,229$ a férfiaknál; $B=1,954$ a nőknél.

\section{Kis vérzéses szövődmények}

Kis vérzéses szövődménynek tekintettük a mútéti seb vérzését, majd serosus váladékozását, illetve a seb körüli bőrfelszínen látható $100 \mathrm{~cm}^{2}$-nél kisebb haematomát.

\section{A mútéti seb vérzésének és serosus váladéko- zásának definíciója, osztályozása}

Sebvérzésnek tekintettük a mútéti sebek vérzését a fedőkötésbe a posztoperatív első 24 órában, egészen a dréncsövek eltávolításáig. Ennek intenzitását az I. táblázat szerint osztályoztuk a dréncsövek eltávolításakor. Serosus sebváladékozásnak tekintettük a csövek eltávolítása után a mútéti seb és a dréncsövek kilépési helyének savós válaciékozását. Ennnek a pontos mennyiségét, azaz fedőkötés átnedvesedés mértékét, a mútét utáni harmadik és hetedik napon ellenőriztük, és az I. táblázatban meghatározott kategóriák szerint feljegyeztük. A váladékozás megszűnését napra pontosan figyeltük.

\section{I. táblázat Sebvérzés (mütét utáni 0-24 óráig) és sebváladékozás kategóriái (dréncsövek eltávolítása után, mútét utáni harmadik és hetedik napon)}

\begin{tabular}{|c|c|}
\hline $\mathbf{0}$ & Tiszta és száraz fedőkötés \\
\hline $\mathbf{1}$ & Pici foltok a fedőkötésen \\
\hline $\mathbf{2}$ & Egy nap alatt a fedőkötés csak egy része nedvesedik át, naponta egyszer kötéscsere \\
\hline $\mathbf{3}$ & $\begin{array}{r}\text { Teljes fedőkötés átnedvesedik egy nap alatt, naponta többször kötéscsere és/vagy a } \\
\text { Mepore }{ }^{\circledR} \text {-ra kiegészítő fedőlapok felhelyezése szükséges }\end{array}$ \\
\hline
\end{tabular}

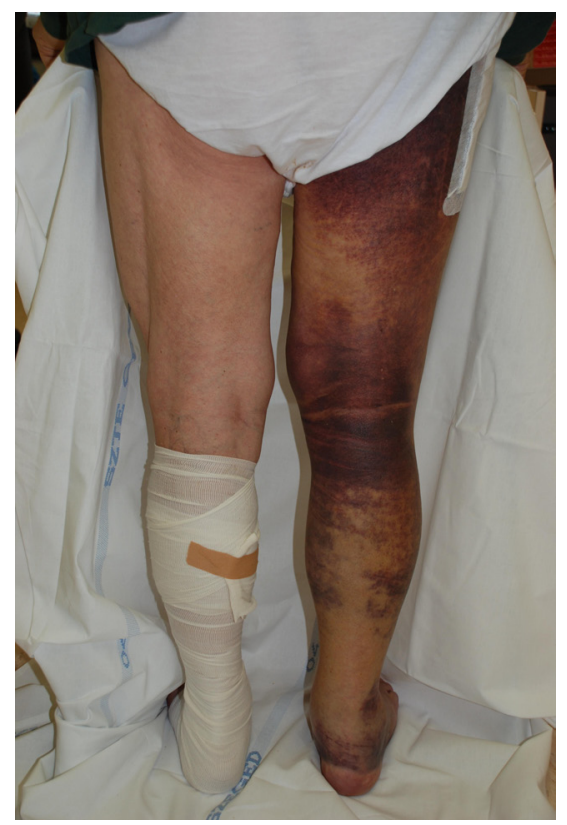

1. ábra Seb körüli haematoma (példa a 6-os kategóriából) 


\section{II. táblázat Haematoma mérete szerinti kategóriák}

\begin{tabular}{|c|c|}
\hline $\mathbf{0}$ & nincs \\
\hline $\mathbf{1}$ & $<100 \mathrm{~cm}^{2}$ \\
\hline $\mathbf{2}$ & $100-200 \mathrm{~cm}^{2}$ \\
\hline $\mathbf{4}$ & $200-300 \mathrm{~cm}^{2}$ \\
\hline $\mathbf{5}$ & $300-400 \mathrm{~cm}^{2}$ \\
\hline $\mathbf{6}$ & $400-500 \mathrm{~cm}^{2}$ \\
\hline
\end{tabular}

\section{Haematoma mérete}

A mútéti seb körüli haematoma (szuffúzió) kiterjedését megbecsültük a bőrfelszínen, majd ez alapján a II. táblázatban látható kategóriákba soroltuk a betegeket (1. ábra).

\section{A combtérfogat változása}

Csípő TEP beültetés után a fokozott serosus váladéktermelődés nem csak sebváladékozás formájában jelentkezhet, hanem akár a comb lágyrészei között felhalmozódva, annak térfogat növekedésével is együtt járhat. Jones és Pearson által kifejlesztett antropometriai módszer az alsó végtagot hat csonka gúlára osztja fel, így igen pontosan kiszámítható annak térfogata (17). Mútét előtt és mútét utáni hetedik napon a méréseket elvégezve könnyen kiszámítható a posztoperatív térfogatváltozás. A combtérfogat kiszámításához a legfelső három csonka gúla adatai elegendőek. A beteg egyenesen, vállszélességnyi terpeszben áll, egymással párhuzamos lábfejekkel. Négy körfogatot mérünk le előre meghatározott magasságokban: 1. a fenékredő magasságában, 2. térdízületi ízrés és fenékredő közti távolság egyharmad magasságában $\left(H / 3=h_{1}\right), 3$. térdízület feletti legkisebb körfogat, 4. térdízület körüli legnagyobb körfogat. A csonka gúlák

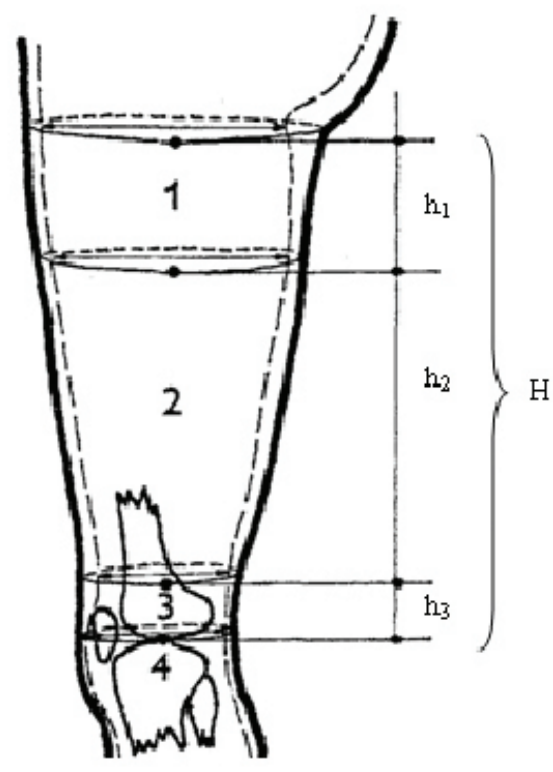

2. ábra A combtérfogat kiszámításához a körfogatok mérésének helyei (17) (magyarázat a szövegben) 
magasságait (azaz a körfogatok közti magasságokat: $h_{1}, h_{2}, h_{3}$ ) testmagasság mérővel (stadiométerrel) határoztuk meg (2. ábra). Ezután kiszámítottuk a csonka gúlák térfogatát, majd azokat összeadva megkaptuk a combtérfogatot.

\section{Statisztika}

Statisztikai elemzéshez a StatSoft ${ }^{\circledR}$ Statistica v.9 programot használtuk, amelyben az adatok feldolgozásához t-próbát, $\mathrm{Chi}^{2}$-próbát és ANOVA-tesztet alkalmaztunk. Adatainkat átlag \pm standard deviáció (SD) formában közöljük. A különbségeket szignifikánsnak tekintettük, ha a p-érték kisebb, mint 0,05.

\section{EREDMÉNYEK}

Vizsgálatunkba összesen 140, mindkét csoportba 70-70 beteget vontunk be. A betegek csoportjait leíró adatok a III. táblázatban láthatóak. A betegeket leíró adatok hasonlóak, nincs közöttük szignifikáns különbség.

Egyetlen betegnél sem alakult ki mélyvénás trombózisra vagy tüdőembóliára utaló tünet a kórházi bennfekvés és a három hónapos utánkövetési időszakban sem, így színkódolt Doppler ultrahangos vizsgálatot, illetve mellkas CTA vizsgálatot ilyen indikációval nem végeztünk. Vizsgálatunk ideje alatt haláleset nem történt.

Az előforduló nagy és klinikailag jelentős vérzéses szövődmények tekintetében nem találtunk különbséget a két csoport között (IV. táblázat). A dabigatran csoportban 22 beteg, míg az enoxaparin csoportban 21 beteg kapott transzfúziót a mútét utáni időszakban.

A mútéti alatti vérveszteséget vizsgálva, nem találtunk különbséget a két csoport között: $300 \mathrm{ml}( \pm 137,2)$ a dabigatran csoportban és $314 \mathrm{ml}( \pm 197,3)$ az enoxaparin csoportban. Nincs jelentős különbség a mútét utáni drénváladék mennyiség tekintetében, amely $470,8 \mathrm{ml}( \pm 276,9)$ volt a dabigatran csoportban és $471,6 \mathrm{ml}( \pm 253,3)$ az enoxaparin csoportban. Hasonló volt a számított perioperatív vérveszteség mennyisége is, mely átlagosan 1072,4 $\mathrm{ml}( \pm 586,6)$ volt a dabigatran csoportban és $1152,3 \mathrm{ml}( \pm 486)$ az enoxaparint kapók csoportjában. A mütét utáni elsö napon nért he.. moglobinesés mértéke nem különbözik a két csoportban, amelynek mértéke $30,7 \mathrm{~g} / \mathrm{l}( \pm 13,5)$ a dabigatrant szedők, és $28,3 \mathrm{~g} / \mathrm{l}( \pm 12,7) \mathrm{az}$ enoxaparint kapók között. Az enoxaparin csoportban 8 beteg és a dabigatran csoportban 3 beteg kapott transzfúziót a mútét utáni első 24 órában, ezért őket nem vettük be a hemoglobinesést a mútét utáni első napon vizsgáló elemzésünkbe. Sebvérzés tekintetében nem találtunk különbséget (V. táblázat).

A haematomák előfordulási gyakorisága és megoszlása az egyes kategóriák között, a VI. táblázatban látható, amely statisztikai elemzések során nem mutatott különbséget.

Mindkét csoporton belül a mútét utáni hetedik napra szignifikánsan megnövekedett a combtérfogat a mútét előtt mért értékekhez hasonlítva, azonban a két csoport között a növekedés mértéke megegyező (3. ábra).

Mindezek ellenére, a két csoport között a fő különbség a serosus sebváladékozás időtartama és intenzitása. A dabigatran csoportban a dréncsövek kilépési helyén 2,3 napig $( \pm 2,7)$, míg az enoxaparin csoportban csupán 1,2 napig $( \pm 1,9)$ volt savós váladékozás a csövek eltávolítása után $(\mathrm{p}<0,05)(4 . a ́ b r a)$. A váladékozás intenzitása is jelentősen nagyobb volt dabigatran csoportban a mútét utáni harmadik és hetedik napon egyaránt a másik csoporthoz viszonyítva $(p<0,05)$ (VII. táblázat és 5. ábra) 


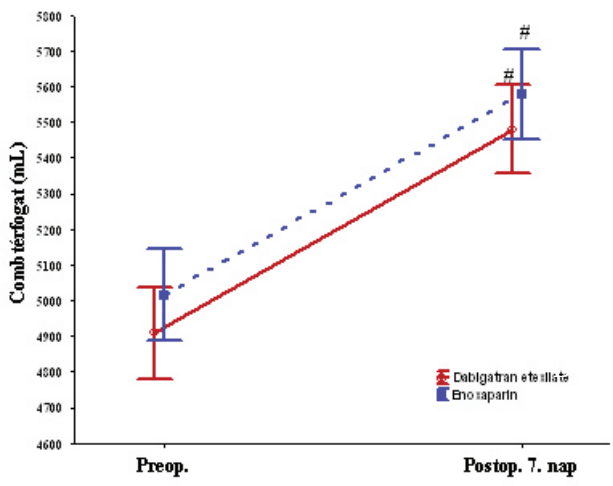

3. ábra Mútét utáni combtérfogat emelkedés

Mindkét csoportban szignifikáns (\#) combtérfogat emelkedés a mütét utáni hetedik napon (Postop. 7. nap) mütét elötti értékhez hasonlítva (Preop.) ( $p<0,05)$, azonban a két csoportot összehasonlítva eltérés nem látható.

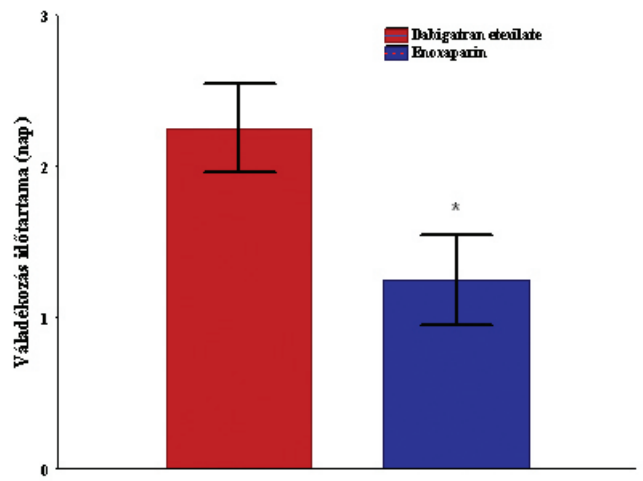

4. ábra Dréncső helyén a váladékozás időtartama (*) szignifikáns különbséget a jelent a két csoport között $(p<0,05)$. A dabigatran csoportban a dréncsövek kilépési helyén 2,3 napig ( $\pm 2,7)$, míg az enoxapirn csoportban 1,2 napig $( \pm 1,9)$ volt serosus váladékozás

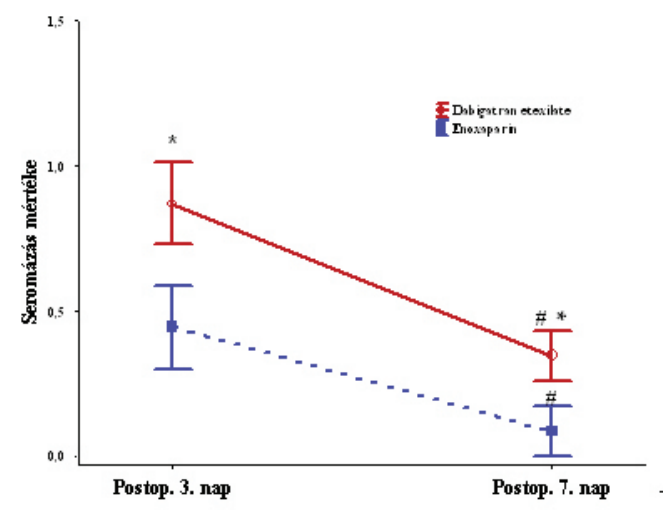

5. ábra Serosus sebváladékozás intenzitása a dréncső helyén

$\left(^{*}\right)$ A sebváladékozás intenzitása is jelentősen nagyobb volt dabigatran csoportban a mútét utáni harmadik (Postop. 3. nap) és hetedik napon (Postop. 7. nap) egyaránt. (\#) Mindkét csoportban a váladékozás mértéke szignifikánsan csökkent a két megfigyelt nap között $(p<0,05)$ 


\begin{tabular}{|c|c|c|}
\hline & Enoxaparin & Dabigatran \\
\hline Betegek száma (n) & 70 & 70 \\
\hline Nem & 19 ช /51 Q & 200 /50 Q \\
\hline Átlagos életkor & $69 \pm 9,7(47-85)$ & $69 \pm 7,6(52-86)$ \\
\hline Testmagasság (cm) & $164 \pm 8,9(150-189)$ & $164 \pm 8,0(148-186)$ \\
\hline Testtömeg (kg) & $77 \pm 14,1(45-100)$ & $76 \pm 11,6(48-99)$ \\
\hline BMI (kg/m2) & $28,5 \pm 4,8(19,1-37,7)$ & $28,3 \pm 4,3(17,9-40,9)$ \\
\hline Becsült vér térfogat (EBV, ml) & $4464 \pm 743,8(2775-6241)$ & $4458 \pm 637,9(2859-5893)$ \\
\hline Hematokrit érték mútét előtt & $0,40 \pm 0,038(0,30-0,50)$ & $0,40 \pm 0,038(0,31-0,50)$ \\
\hline Hemoglobin mútét előtt (g/l) & $134,7 \pm 15,7(94-176)$ & $135,9 \pm 13,5(101-172)$ \\
\hline Mútét időtartama (perc) & $77 \pm 18,8(50-140)$ & $74 \pm 15,8(50-120)$ \\
\hline $\begin{array}{c}\text { Anesztézia } \\
\text { általános/regionális/ } \\
\text { kombináció }\end{array}$ & $19 / 41 / 10$ & $19 / 40 / 11$ \\
\hline
\end{tabular}

\begin{tabular}{|c|c|c|}
\hline & Enoxaparin $(n=70)$ & Dabigatran $(n=70)$ \\
\hline $\begin{array}{c}\text { Azonnali } 2 \text { vagy annál több egység vörösvértest koncentrá- } \\
\text { tum transzfúzióját igénylő vérzés }\end{array}$ & $4(5,7)$ & $5(7,1)$ \\
\hline Mútéti seb körüli bőr felszíni hematóma $\geq 100$ cm2 & $29(41,4)$ & $33(47,1)$ \\
\hline $\begin{array}{l}\text { Spontán és/vagy beavatkozás során kialakuló makroszkó- } \\
\text { pos hematuria > } 24 \text { óra }\end{array}$ & $0(0)$ & $1(1,4)$ \\
\hline
\end{tabular}

\section{V. táblázat Sebvérzések elöfordulása a két csoportban}

\begin{tabular}{|c|c|c|c|c|}
\hline Kategória: & $\mathbf{0}$ & $\mathbf{1}$ & $\mathbf{2}$ & $\mathbf{3}$ \\
\hline Enoxaparin $(n=70)$ & 2 & 24 & 16 & 19 \\
\hline Dabigatran $(n=70)$ & $(2,9)$ & $(34,3)$ & $(22,9)$ & $(27,1)$ \\
\hline & 1 & 23 & 18 & 19 \\
\hline
\end{tabular}

A számok az esetszámokat mutatják, zárójelben a százalékos arány (\%). Az egyes kategóriák meghatározása az I. táblázatban látható.

\begin{tabular}{|c|c|c|c|c|c|c|c|c|}
\hline \multicolumn{1}{|c|}{ VI. táblázat Haematomák elöfordulása a vizsgálatunkban } \\
\hline Kategória: & 0 & 1 & 2 & 3 & 4 & 5 & 6 \\
\hline Enoxaparin $(n=70)$ & 23 & 9 & 6 & 10 & 4 & 2 & 7 \\
\hline Dabigatran $(n=70)$ & $(32,9)$ & $(12,9)$ & $(8,6)$ & $(14,3)$ & $(5,7)$ & $(2,9)$ & $(10,0)$ \\
\hline & 22 & 6 & 15 & 6 & 5 & 5 & 2 \\
& $(31,4)$ & $(8,6)$ & $(21,4)$ & $(8,6)$ & $(7,1)$ & $(7,1)$ & $(2,9)$ \\
\hline
\end{tabular}

A számok az esetszámokat mutatják, zárójelben a százalékos arány (\%). Az egyes kategóriák meghatározása a II. táblázatban látható. 
VII. táblázat A betegek eloszlása a serosus sebváladékozás intenzitása alapján felosztott kategóriák között a mütét után harmadik és hetedik napon

\begin{tabular}{|c|c|c|c|c|c|c|c|c|}
\hline \multirow{2}{*}{ Kategória: } & \multicolumn{4}{|c|}{ Mútét utáni 3. nap } & \multicolumn{4}{c|}{ Mútét utáni 7. nap } \\
\cline { 2 - 11 } & Össz. & $\mathbf{1}$ & $\mathbf{2}$ & $\mathbf{3}$ & Össz. & $\mathbf{1}$ & $\mathbf{2}$ & $\mathbf{3}$ \\
\hline Enoxaparin $(\mathrm{n}=70)$ & 13 & 5 & 2 & 6 & 3 & 2 & 0 & 1 \\
& $(18,6)$ & $(7,1)$ & $(2,9)$ & $(8,6)$ & $(4,3)$ & $(2,9)$ & $(0)$ & $(1,4)$ \\
\hline Dabigatran $(\mathrm{n}=70)$ & 23 & 7 & 2 & 14 & 10 & 3 & 3 & 4 \\
& $(32,9)$ & $(10,0)$ & $(2,9)$ & $(20,0)$ & $(14,3)$ & $(4,3)$ & $(4,3)$ & $(5,7)$ \\
\hline
\end{tabular}

A számok az esetszámokat mutatják, zárójelben a százalékos arány (\%). Az egyes kategóriák meghatározása az I. táblázatban látható.

\section{MEGBESZÉLÉS}

A csípő TEP beültetés után a MVT és PE kialakulásának veszélye igen fokozott (11). Trombózis kialakulást megelőző módszerek alkalmazása nélkül, venográfiás vizsgálattal, akár az esetek 42-60\%-ban tünetmentes MVT és 16-32\%-ban tünetmentes PE jelenléte igazolható (4).

A Magyar Egészségügyi Minisztérium tromboemboliák kockázatának csökkentéséről és kezeléséről szóló érvényes szakmai ajánlása szerint (22), a csípő TEP beültetés után gyógyszeres tromboprofilaxist kell alkalmazni, amivel a tüneteket okozó MVT kockázata 2-5\%-ra, a PE-é 0,2\%-ra csökkenthető. Subcutan módon adható bármely profilaxisra törzskönyvezett LMWH készítmény, illetve a fondaparinux (evidencia szint 1A). Szájon keresztül szedhető perioperatív tromboprofilaxisra használható a rivaroxaban és a dabigatran (ajánlási szint nincs megjelölve).

A Mellkas Gyógyászok Amerikai Kollégiumának (American College of Chest Physicians, ACCP) és az Amerikai Ortopéd Sebészek Akadémiájának (American Academy of Orthopaedic Surgeons, AAOS) 2012-es ajánlása szerint, csípő TEP beültetés után perioperatív trombózismegelőzés céljából LMWH, UFH, fondaparinux, apixaban, dabigatran, rivaroxaban, acetilszalicil-sav és KVA-k (mindegyiknél az ajánlás evidencia szintje 1B), illetve periódikusan pumpáló alsó végtagi pneumatikus eszközök (evidencia szint 1C) használhatóak (13). Az ajánlási szintek közti különbséget az adja, hogy az AAOS szerint az eddigi vizsgálatok során nem helyesen, a venográfiával igazolt MVT megelőzésére helyezték a hangsúlyt, így az eddig használt tromboprofilaktikus protokollokkal együtt megemelkedett a vérzési szövődmények száma is. A legújabb vizsgálatokkal, amelyeknél a tünetet okozó VTE a biztonsági végpont, azt szeretnék bizonyítani, hogy kis rizikójú csoportban, az elektív csípő és térd protézis beültetés után elegendő $a z$ acetilszalicil-sav és pneumatikus eszközök kombinációja a VTE szövődmények megelőzésére, csökkentve ezzel a vérzéses szövődmények gyakoriságát is (3).

Évtizedek óta a mai napig, az LMWH-kat tekintjük a tromboprofilaxis bázisszerének (23). Európában az enoxaparin az egyik legkedveltebb subcutan alkalmazható LMWH típusú antikoaguláns, amit a dabigatran etexilát kifejlesztése során is összehasonlító hatóanyagként használtak. A direkt trombin gátló dabigatran megfigyelésekor, mint biztonsági végpontokra, komoly hangsúlyt helyeztek a nagy és klinikai szempontból jelentős vérzéses szövődményekre. A kis vérzéses szövődmények és a sebgyógyulást befolyásoló hatások a vizsgálatok során a háttérbe szorultak és azokat csak érintőlegesen közölték (5-8).

A BISTRO I vizsgálatban a dabigatran etexilát biztonságos terápiás dózistartományát határozták meg csípő TEP beültetés után (5). A klinikailag jelentős vérzéses szövődményeket a vizsgálat során nem gyűjtötték külön osztályba, azok mind a kis vérzéses szövődmények kategóriájába kerültek. A nagy vérzéses szövődmények teljes hiányát és a kis vérzéses szövődmények igen magas számát a megfigyelési irányelvek pontatlan meghatározásával magyarázták.

Különböző dózisú dabigatran terápiák hatékonyságát és biztonságosságát figyelték a BISTRO II vizsgálatban (6). Azokban a 
csoportokban, ahol a betegek nagyobb dózisú dabigatrant kaptak, az szignifikánsan hatékonyabbnak bizonyult a kontrollcsoportként megfigyelt enoxaparinnál, azonban szignifikánsan nagyobb számban alakultak ki vérzéses szövődmények is.

A RE-NOVATE vizsgálat során bebizonyították, hogy a $150 \mathrm{mg}$ dabigatran 75 éves kor felett, illetve a $220 \mathrm{mg}$ dabigatran 75 éves kor alatt ugyanolyan hatékony VTE megelőzés szempontjából, mint a $40 \mathrm{mg}$ enoxaparin (8). Biztonság szempontjából sem volt különbség a két szer között.

A RE-NOVATE II vizsgálattal igazolták, hogy csípő TEP beültetés esetében a $220 \mathrm{mg}$ dabigatrant és a $40 \mathrm{mg}$ enoxaparint használva a vérzéses szövődmények gyakorisága megegyezik, a két szer biztonsági profilját hasonlónak találták (7). A kutatásról szóló publikációkban azonban nem tértek ki, csak összesített adatként közlik a klinikai szempontból jelentős, és a kis vérzéses szövődményeket. A vizsgálati eredményeket áttekintve, nagyobb a vérzéses szövődmények előfordulási gyakorisága dabigatrant használva, úgy hogy a kis vérzéses szövődmények vizsgálata és pontos közlése a háttérbe szorult a fó biztonságossági és hatékonysági kritériumok megfigyelése mellett.

A jelenleg érvényben levő magyarországi és nemzetközi irányelvek szerint, csípőprotézis beültetés után a VTE megelőzés ajánlott időtartama 28-35 nap $(11,13,19)$.

$\mathrm{Az}$ enoxaparin igen megbízható és biztonságos szernek bizonyult több évtizedes használata során, habár az injekciós kiszerelés és subcutan beadási mód problémát jelenthet intézeten kívüli alkalmazáskor. További hátrányai az indirekt hatásmechanizmus, a heparin indukálta trombocytopenia (HIT), a rövid féléletidő és állati eredet miatt kialakuló allergiás reakciók (14). Szükség esetén azonban jól monitorizálható a szer hatékonysága az aktivált parciális tromboplasztin idő (activated partial tromboplastin time, aPTT) és a trombocytaszám ellenőrzésével, illetve a protamin-szulfátot antidótumként alkalmazhatjuk reverz hatás kialakítására (11).

A fentebb részletezett vizsgálatok a dabigatrant az LMWH-kal megegyezően hatásosnak és biztonságosnak találták, ám az nem rendelkezik a korábban említett mellékhatásokkal és a szájon keresztüli alkalmazhatósága is népszerúbbé teheti a betegek körében. Hátránya azonban, hogy hatékonyságát nem tudjuk monitorizálni, illetve nem létezik antidótuma (11). Az LMWH-k széleskörű felhasználhatóságával ellentétben, a dabigatrannal továbbra is számos vizsgálat folyik, annak előrejósolt indikációs köre beszűkülni látszik. Eddigi eredmények alapján az Országos Gyógyszerészeti Intézet kiadványa szerint az csak elektív csípő és térd TEp beültetést kJ̈vetően vénás tromboprofilaxis céljából, illetve nem múbillentyút viselő pitvarfibrillációban szenvedő betegeknél stroke és szisztémás embólia prevenciójára használható.

Klinikai gyakorlatunk során a dabigatran használatakor gyakrabban jelentkező nagyobb mennyiségű és elhúzódó serosus sebváladékozások miatt átnéztük a gyógyszer kifejlesztésének hátterét. Korábban a dabigatrannal ilyen részletes, a mútéti seb gyógyulását befolyásoló tényezőket megfigyelő prospektív vizsgálat nem készült. Az Egyesült Királyságban egy központi kórház ortopédiai osztályán retrospektív vizsgálattal elhúzódó sebváladékozást és gyakoribb reoperációs rátát figyeltek meg dabigatran használatakor. Vizsgálatukra alapozva a korai mútét utáni időszakban az intézeti körülmények között továbbra is LMWH-t, dalteparint adnak, majd a betegeket otthonukba bocsátva kezdik csak el a dabigatran alkalmazását (12).

Annak ellenére, hogy a vizsgálatunk viszonylag kis esetszámmal rendelkezik, mégis szignifikáns különbséget találtunk a sebváladékozás időtartamában és mennyiségében, illetve a csoportokon belül a combtérfogat változásban. Nincs különbség azonban, a mútéti seb körül kialakult haematoma méretében és elöfordulási gyakoriságban a két szer között. Megfigyelésünk és a dolgozat határain túlmutat, hogy pontos farmakológiai magyarázatot adjunk a gyakrabban kialakuló kis vérzéses és sebgyógyulási szövődményekre, azonban feltételezhetjük, hogy a dabigatran mútét utáni túl korai alkalmazása lehet a háttérben. Az érvényben levő ACCP trombózist megelőző irányelvei szerint, a mútét után leghamarabb csak 12 órával ajánlott az antikoagulánsok beadása az ettől korábbi időpontot megjelölő gyártói ajánlások ellenére $(11,13)$.

Egy 1981-ben megjelent publikációban a protézis posztoperatív fertőzéses rizikófaktorai között szerepel az antikoaguláns terápia okozta 
elhúzódó savós váladékozás és nagyobb kiterjedésű haematoma (1). Ellentmondásos, hogy az elhúzódó sebváladékozás okozhat-e késői periprotetikus fertőzéses szövődményt (1), de néhány szerző talált összefüggést a kettő között (24). Biztosan állíthatjuk viszont, hogy az elhúzódó sebváladékozás miatt a betegek hosszabb hospitalizációra szorulnak, megnövelve ezzel az ellátás költségeit (4).

Vizsgálatunknak számos erőssége és gyengesége is van. Egyetlen, nagy esetszámmal dolgozó intézet adatait dolgozza fel, ugyanazt a mútéti technikát alkalmazva minden beteg esetében. Egy vizsgáló prospektív módon figyelte és mérte le a betegek adatai. A betegek kiinduló alapadatai megegyeztek a két csoportban. A mútét körüli vérveszteséget alaposan, több szempontból is figyeltük (mútét alatti vérveszteség, drénváladék, hemoglobin koncentráció, seb hematoma mérete). Kutatásunk esetszáma nem engedi meg, hogy egyértelmű következtetést tegyünk az alkalmazott antikoagulánsok miatt kialakuló sebszövődmények és az amiatt szükséges reoperációk számára, arányára.

Vizsgálatunkban dabigatran használata során elhúzódó ideig és nagyobb menynyiségben tapasztaltunk serosus sebváladékozást a dréncsövek kilépési helyén. Eredményeink alapján további nagy populációval dolgozó multicenter vižsgálatok feláilítása lenne szükséges, hogy vizsgálja a dabigatran használatakor jelentkező kis vérzéses szövődmények sebgyógyulást és sebfertőződést befolyásoló hatását, illetve újragondolja a hatóanyag alkalmazásának megfelelő indikációs körét.

\section{Köszönetnyilvánítás}

Szeretnénk megköszönni Dr. Szalárdy Levente önzetlen munkáját és segítségét a statisztikai elemzés elvégzésében. 


\section{IRODALOM}

1. Andrews H. J., Arden G. P., Hart G. M., Owen J. W.: Deep infection after total hip replacement. J. Bone Joint Surg. Br. 1981. 63-B. (1): 53-57.

2. Arcelus J. I., Kudrna J. C., Caprini J. A.: Venous thromboembolism following major orthopedic surgery: what is the risk after discharge? Orthopedics, 2006. 29. (6): 506-516.

3. Barrack R. L.: Thromboprophylaxis for patients undergoing joint replacement. Bone Joint J. 2014. 96-B. (1): 3-4.

4. Bonnevialle P., Bonnomet F., Philippe R., Loubignac F., Rubens-Duval B., Talbi A., Le Gall C., Adam P.: Early surgical site infection in adult appendicular skeleton trauma surgery: A multicenter prospective series. Orthop. Traumatol. Surg. Res. 2012. 98. (6): 684-689.

5. Eriksson B. I., Dahl O. E., Ahnfelt L., Kalebo P., Stangier J., Nehmiz G., Hermansson K., Kohlbrenner V.: Dose escalating safety study of a new oral direct thrombin inhibitor, dabigatran etexilate, in patients undergoing total hip replacement: BISTRO I. J. Thromb. Haemost. 2004. 2. (9): 1573-1580.

6. Eriksson B. I., Dahl O. E., Buller H. R., Hettiarachchi R., Rosencher N., Bravo M. L., Ahnfelt L., Picueillú r., Stüingier J., Kũlebo R?, Reilly P.: A new oral direct thrombin inhibitor, dabigatran etexilate, compared with enoxaparin for prevention of thromboembolic events following total hip or knee replacement: the BISTRO II randomized trial. J. Thromb. Haemost. 2005. 3. (1): 103-111.

7. Eriksson B. I., Dahl O. E., Huo M. H., Kurth A. A., Hantel S., Hermansson K., Schnee J. M., Friedman R. J.: Oral dabigatran versus enoxaparin for thromboprophylaxis after primary total hip arthroplasty (RE-NOVATE II*). A randomised, double-blind, non-inferiority trial. Thromb. Haemost. 2011. 105. (4): 721-729.

8. Eriksson B. I., Dahl O. E., Rosencher N., Kurth A. A., van Dijk C. N., Frostick S. P., Prins M. H., Hettiarachchi R., Hantel S., Schnee J., Buller H. R.: Dabigatran etexilate versus enoxaparin for prevention of venous thromboembolism after total hip replacement: a randomised, double-blind, non-inferiority trial. Lancet, 2007. 370. (9591): 949-956.

9. European Medicines Agency, Committee for Medicinal Products for Human Use (CHMP): Guideline on clinical investigation of medicinal products for prophylaxis of high intra-and post-operative venous thromboembolic risk. 2008. Available at http://www.ema.europa.eu/ docs/en_GB/document_library/Scientific_guideline/2009/09/WC500003301.pdf

10. Evarts C. M., Feil E. J.: Prevention of thromboembolic disease after elective surgery of the hip. J. Bone Joint Surg. Am. 1971. 53. (7): 12711280.

11. Falck-Ytter Y., Francis C. W., Johanson N. A., Curley C., Dahl O. E., Schulman S., Ortel T. L., Pauker S. G., Colwell C. W., Jr.: Prevention of VTE in orthopedic surgery patients: Antithrombotic Therapy and Prevention of Thrombosis, 9th ed: American College of Chest Physicians Evidence-Based Clinical Practice Guidelines. Chest, 2012. 141. (2. Suppl.): e278S-325S.

12. Gill S. K., Theodorides A., Smith N., Maguire E., Whitehouse S. L., Rigby M. C., Ivory J. P.: Wound problems following hip arthroplasty before and after the introduction of a direct thrombin inhibitor for thromboprophylaxis. Hip Int. 2011. 21. (6): 678-683.

13. Guyatt G. H., Akl E. A., Crowther M., Gutterman D. D., Schuunemann H. J.: Executive summary: Antithrombotic Therapy and Prevention of Thrombosis, 9th ed: American College of Chest Physicians Evidence-Based Clinical Practice Guidelines. Chest, 2012. 141. (2. Suppl.): $75-47 S$.

14. Hirsh J., Bauer K. A., Donati M. B., Gould M., Samama M. M., Weitz J. I.: Parenteral anticoagulants: American College of Chest Physicians Evidence-Based Clinical Practice Guidelines (8th Edition). Chest, 2008. 133. (6. Suppl.): 141S-159S.

15. Hull R. D., Pineo G. F., Francis C., Bergqvist D., Fellenius C., Soderberg K., Holmqvist A., Mant M., Dear R., Baylis B., Mah A., Brant R.: Low-molecular-weight heparin prophylaxis using dalteparin in close proximity to surgery vs warfarin in hip arthroplasty patients: a double-blind, randomized comparison. The North American Fragmin Trial Investigators. Arch. Intern. Med. 2000. 160. (14): $2199-2207$.

16. Jameson S. S., Rymaszewska M., Hui A. C., James P., Serrano-Pedraza I., Muller S. D.: Wound complications following rivaroxaban administration: a multicenter comparison with low-molecular-weight heparins for thromboprophylaxis in lower limb arthroplasty. J. Bone Joint Surg. Am. 2012. 94. (17): 1554-1558.

17. Jones P. R., Pearson J.: Anthropometric determination of leg fat and muscle plus bone volumes in young male and female adults. J. Physiol. 1969. 204. (2): 63P-66P.

18. Nadler S. B., Hidalgo J. H., Bloch T.: Prediction of blood volume in normal human adults. Surgery 1962. 51. (2): $224-232$.

19. National Institute for Health and Care Excellence (NICE): Venous thromboembolism: reducing the risk. NICE clinical guideline 92. 2010. Available: $h$ ttp://guidance.nice.org.uk/CG92/NICEGuidance/pdf/English

20. Szücs G., Benkő K., Bene S., Simon T.: Pre- és posztoperativ Color Doppler Ultrahang vizsgálatok jelentősége nagyízületi endoprotézis mütétek thromboembóliás profilaxisában. Magyar Traumatológia Ortopédia Kézsebészet Plasztikai Sebészet, 1999. 42. (1): 28-33.

21. Szücs G., Muszbek L., Szepesi K., Ajzner É., Simon T., Fülesdi B.: A tromboembóliás szövődményekre hajlamosító tényezők vizsgálata ortopédiai protézisek beültetése esetén. Aneszteziológia és Intenzív Terápia, 2009. (39): 17-23.

22. Transzfúziológiai és Hematológiai Szakmai Kollégium, Magyar Thrombosis és Haemostasis Társaság: A Magyar Egészségügyi Minisztérium szakmai irányelve: A thromboembóliák kockázatának csökkentéséröl és kezeléséröl. (1. módosított változat). Egészségügyi Közlöny, 2010. (4): 1214-1283.

23. Warwick D.: Prevention of venous thromboembolism in total knee and hip replacement. Circulation, 2012. 125. (17): $2151-2155$.

24. Wilson P.D., Jr.: Joint replacement. South Med. J. 1977. 70. Suppl. 1. 55-60.

\section{Dr. Gombár Csaba}

\section{SZTE ÁOK Ortopédiai Klinika}

6725 Szeged, Semmelweis u. 6.

E-mail: gombar.csaba@med.u-szeged.hu

Tel.: 06 (62) 545-423 